\title{
INFORMACJE O PRZYNALEŻNOŚCI ZWIĄZKOWEJ JAKO DANE CHRONIONE SZCZEGÓLNEJ KATEGORII
}

\author{
Abstract \\ Personal data revealing trade union membership as special categories of personal data
}

Personal data revealing trade union membership are qualified as special categories of personal data because of the importance of this information and its significant impact on the situation of a natural person. It is worth mentioning in particular that trade union membership may be a premise for unequal treatment of workers. Ensuring an adequate level of protection of this information is therefore of fundamental importance.

Słowa kluczowe: przynależność związkowa, ochrona danych osobowych, RODO

Keywords: trade union membership, personal data protection, GDPR

ASCJ: 3308, JEL: K31

\section{Uwagi wstępne}

Kwalifikacja informacji o przynależności związkowej jako danych szczególnie chronionych na mocy przepisów o ochronie danych osobowych jest z całą pewnością wyrazem przekonania prawodawcy o doniosłym znaczeniu tych informacji i ich istotnym wpływie na sytuację osoby fizycznej. Podkreślić zwłaszcza wypada, że przynależność do organizacji związkowej może stanowić przesłankę nierównego traktowania osób zatrudnionych. Zapewnienie właściwego poziomu ochrony w zakresie dostępu do przedmiotowych danych ma zatem fundamentalne znaczenie. Celem niniejszego opracowania jest analiza charakteru prawnego tytułowej kategorii danych. 


\section{Założenia ochrony danych osobowych szczególnej kategorii}

Dokonana w ostatnich latach unijna reforma prawa ochrony danych osobowych nie wpłynęła istotnie na kształt instytucji ochrony tak zwanych danych wrażliwych (sensytywnych), choć dokonano pewnej modyfikacji zakresu przedmiotowej kategorii danych. Nie zmieniło się zwłaszcza założenie o konieczności zapewnienia szczególnej ochrony informacjom określonego rodzaju, które - z uwagi na swój specyficzny charakter - wymagają dodatkowego zabezpieczenia. Jak wynika z motywu 51 preambuły rozporządzenia Parlamentu Europejskiego i Rady (UE) nr 2016/679 z dnia 27 kwietnia 2016 roku w sprawie ochrony osób fizycznych w związku z przetwarzaniem danych osobowych i w sprawie swobodnego przepływu takich danych oraz uchylenia dyrektywy 95/46/WE (Dz.Urz. UE L 2016, nr 119, dalej: RODO), celem jest tutaj ochrona podstawowych praw i wolności osoby, której dane dotyczą, w kontekście przetwarzania danych wrażliwych, które generuje szczególne zagrożenia. Prawodawca unijny zaliczył do nich ryzyko dyskryminacji, wskazując w motywie 71 preambuły RODO, że należy zapobiegać dyskryminacji osób fizycznych między innymi ze względu na przynależność do związków zawodowych - z całą pewnością kryterium przynależności związkowej może być przesłanką nierównego traktowania. Zwraca na to uwagę także ustawodawca krajowy. Na mocy art. 3 ust. 1 ustawy z dnia 23 maja 1991 roku o związkach zawodowych (Dz.U. 2019, poz. 263 tekst jedn., dalej: ustawa o związkach zawodowych, u.z.z.) ustanawia się zakaz nierównego traktowania w zatrudnieniu z powodu przynależności do związku zawodowego lub pozostawania poza nim albo wykonywania funkcji związkowej (Wujczyk 2019, s. 204 i n.). Kryterium przynależności związkowej wskazuje się również wśród cech prawnie chronionych na gruncie art. $18^{3 \mathrm{a}}$ $\$ 1$ ustawy z dnia 26 czerwca 1974 roku - Kodeks pracy (Dz.U. 2019, poz. 1040 tekst jedn. ze zm., dalej: k.p.).

Przejawem szczególnej ochrony danych wrażliwych jest generalny zakaz ich przetwarzania. W świetle art. 9 ust. 1 RODO zabrania się przetwarzania danych osobowych ujawniających pochodzenie rasowe lub etniczne, poglądy polityczne, przekonania religijne lub światopoglądowe, przynależność do związków zawodowych, jak również danych genetycznych, danych biometrycznych służących jednoznacznej identyfikacji osoby fizycznej oraz danych dotyczących zdrowia, seksualności lub orientacji seksualnej tej osoby. Powyższy zakaz nie ma jednak charakteru bezwzględnego, w art. 9 ust. 2 RODO przewiduje się bowiem katalog okoliczności uchylających ten zakaz. Jest to katalog zamknięty, a zatem przesłanki inne niż wymienione $\mathrm{w}$ treści powyższej regulacji nie legalizują przetwarzania danych szczególnie chronionych. Wprawdzie podstawy prawne przetwarzania tak zwanych danych zwykłych zostały ujęte w art. 6 ust. 1 RODO także w sposób wyczerpujący, jednak wśród przesłanek legalności przetwarzania danych wrażliwych nie uwzględniono takich okoliczności jak zawarcie lub wykonanie umowy czy też realizacja prawnie uzasadnionego interesu administratora danych osobowych. Przesłanki te mają istotne znaczenie praktyczne w procesach przetwarzania danych osobowych innych niż dane szczególnie chronione. $Z$ uwagi na wyższy standard ochrony 
danych sensytywnych powyższe okoliczności nie uchylają zakazu przetwarzania wynikającego $\mathrm{z}$ art. 9 ust. 1 RODO.

Specyficzny charakter informacji zaliczanych do kategorii danych wrażliwych bez wątpienia uzasadnia przyjęcie szczególnego modelu ochrony prawnej tych danych. Są to bowiem dane związane ze sferą prywatności, a nawet intymności człowieka. Dostęp do nich wymaga więc wzmożonej ochrony służącej zabezpieczeniu prywatności osób fizycznych, jak również przeciwdziałaniu ich dyskryminacji ze względu na cechy wskazane w art. 9 ust. 1 RODO.

\section{Status prawny informacji o przynależności związkowej}

Status prawny informacji o przynależności związkowej na gruncie przepisów o ochronie danych osobowych nie uległ zmianie w związku z uchwaleniem nowego aktu prawnego regulującego zasady przetwarzania danych osobowych w Unii Europejskiej. Już w art. 8 ust. 1 dyrektywy 95/46/WE Parlamentu Europejskiego i Rady z dnia 24 października 1995 roku w sprawie ochrony osób fizycznych w zakresie przetwarzania danych osobowych i swobodnego przepływu tych danych (Dz.Urz. UE L 1995, nr 281) dane te zakwalifikowano jako dane chronione szczególnej kategorii. W rezultacie także polski ustawodawca, przyjmując $w$ art. 27 ust. 1 poprzednio obowiązującej ustawy z dnia 29 sierpnia 1997 roku o ochronie danych osobowych (Dz.U. 2016, poz. 922 tekst jedn. ze zm.) definicję danych wrażliwych, uwzględnił w niej informacje ujawniające przynależność związkową. W aktualnym stanie prawnym dane dotyczące przynależności do organizacji związkowej zostały ujęte w katalogu danych szczególnie chronionych zawartym w art. 9 ust. 1 RODO.

Zakres podmiotowy wskazanej kategorii danych wynika z art. 2 u.z.z., określającego krąg osób uprawnionych do przystępowania do związków zawodowych i/lub ich tworzenia. Do osób, którym przysługuje prawo przynależności do związków zawodowych, należą między innymi: osoby wykonujące pracę zarobkową, emeryci, renciści, osoby bezrobotne, wolontariusze, stażyści i inne osoby świadczące osobiście pracę bez wynagrodzenia oraz osoby skierowane do pracodawców w celu odbycia służby zastępczej. Przedmiotowe informacje dotyczyć będą wyłącznie osób fizycznych, które skorzystały $\mathrm{z}$ uprawnienia wynikającego $\mathrm{z}$ art. 2 u.z.z. i zostały przyjęte do organizacji związkowej. Podkreślić bowiem trzeba, że spełnienie powyższego kryterium podmiotowego nie zawsze obliguje organizację związkową do podjęcia decyzji o przyznaniu wnioskodawcy statusu członkowskiego.

Jednocześnie zauważyć wypada, że przepisy ustawy o związkach zawodowych wyróżniają też inną niż osoby należące do organizacji związkowych kategorię osób. Zgodnie z art. 7 ust. 3 u.z.z. na wniosek osoby niezrzeszonej związek zawodowy może się podjąć obrony jej praw i interesów wobec pracodawcy. Informacje na temat takich osób nie mają natomiast statusu danych szczególnie chronionych, nie są to bowiem dane ujawniające przynależność związkową (Kulesza 2017, s. 188) - wręcz przeciwnie, są to informacje 
wskazujące na brak przynależności do organizacji związkowej. Wyrażam przekonanie, iż danymi sensytywnymi są wyłącznie informacje dotyczące przynależności związkowej, nie zaś jej braku, choć w perspektywie respektowania nakazu równego traktowania w zatrudnieniu rozstrzygnięcie tej kwestii nie ma w zasadzie znaczenia.

Zaznaczyć wreszcie trzeba, że omawiana kategoria informacji odnosi się do kwestii uczestnictwa wyłącznie w jednego typu organizacji reprezentującej interesy ludzi pracy - w związkach zawodowych - co zapewne jest podyktowane ich szczególną pozycją prawną i charakterem prowadzonej przez nie działalności. Specyfika funkcjonowania rad pracowników, których status prawny określają przepisy ustawy z dnia 7 kwietnia 2006 roku o informowaniu pracowników i przeprowadzaniu z nimi konsultacji (Dz.U. 2006, $\mathrm{nr} 79$, poz. 550 ze zm., dalej: u.i.p.), jest zupełnie inna. Jako że pracodawca jest zaangażowany w tworzenie rady pracowników, wiedza dotycząca uczestnictwa przedstawicieli pracowników w radzie pracowników jest dla pracodawcy dostępna ${ }^{1}$. Brak zatem potrzeby zapewniania szczególnej ochrony w odniesieniu do danych dotyczących uczestnictwa w radzie pracowników, inaczej niż w przypadku członkostwa osób, które nie biorą czynnego udziału w działalności organizacji związkowej.

\section{Podstawy prawne przetwarzania informacji o przynależności związkowej}

Kluczową kwestią dla ustalenia legalności procesów przetwarzania informacji o przynależności związkowej jest określenie, które podstawy prawne przetwarzania danych sensytywnych znajdują w tym wypadku zastosowanie. Podkreślić przy tym wypada, że ustawodawca krajowy nie jest uprawniony do poszerzania katalogu okoliczności legalizujących przetwarzanie danych osobowych określonego przepisami RODO. Może jedynie dokonać ich uszczegółowienia w drodze przepisów prawa krajowego.

Przesłanką, która $\mathrm{z}$ całą pewnością stanowić będzie podstawę prawną przetwarzania informacji o przynależności związkowej jako danych szczególnie chronionych, jest okoliczność wskazana w art. 9 ust. 2 lit. b RODO. W świetle powyższej regulacji przetwarzanie tych danych jest dopuszczalne, jeśli jest niezbędne do realizacji szczególnych praw i obowiązków przez administratora lub podmiot danych osobowych między innymi w dziedzinie prawa pracy, o ile jednak jest to dozwolone prawem unijnym, prawem krajowym lub porozumieniem zbiorowym wydanym na mocy prawa krajowego przewidującymi odpowiednie zabezpieczenia praw podstawowych i interesów podmiotu danych. Wskazana przesłanka ma zatem charakter generalny i wymaga doprecyzowania w drodze odrębnych przepisów prawnych. Jak sądzę, będzie ona miała zastosowanie przede wszystkim w kontekście przetwarzania przez pracodawcę informacji o przynależności związkowej pracowników, choć przypuszczać należy, że ratio legis omawianej

${ }^{1}$ Krytycznie na temat kompetencji pracodawcy do decydowania o procedurze tworzenia rady pracowników: Hajn 2017, s. 586 i n. 
przesłanki było odniesienie jej do przetwarzania danych wrażliwych osób zatrudnionych na jakiejkolwiek podstawie prawnej (nie zaś tylko pracowników)22.

Do uregulowanych explicite w prawie polskim okoliczności, w których dopuszczalne jest przetwarzanie przez pracodawcę informacji o przynależności związkowej, należy przykładowo realizacja obowiązku pobierania $\mathrm{z}$ wynagrodzenia za pracę składki związkowej. W myśl art. $33^{1}$ ust. 1 u.z.z. na pracodawcy spoczywa powyższa powinność w sytuacji, gdy zakładowa organizacja związkowa złożyła w tej sprawie pisemny wniosek, a pracownik (lub inna osoba wykonująca pracę zarobkową) wyraził na to zgodę na piśmie $^{3}$. Nie ma wątpliwości, że przetwarzane przez administratora dane osobowe mają status danych szczególnie chronionych, jako że są to informacje ujawniające przynależność związkową pracownika (lub innej osoby wykonującej pracę zarobkową). W świetle art. 9 ust. 2 lit. b RODO zakaz przetwarzania tych danych zostaje uchylony w związku z koniecznością spełnienia obowiązku prawnego administratora danych osobowych (podmiotu zatrudniającego) i jednocześnie wykonania uprawnienia osoby, której dane dotyczą (osoby wykonującej pracę zarobkową).

Rozważenia wymaga dopuszczalność przetwarzania wskazanych danych w związku z konsultacją związkową dokonywaną przez pracodawcę zamierzającego wypowiedzieć pracownikowi umowę o pracę zawartą na czas nieokreślony. Zgodnie z art. 38 k.p. pracodawca jest zobowiązany zawiadomić o takim zamiarze reprezentującą pracownika zakładową organizację związkową, a zatem w pierwszej kolejności musi ustalić, czy pracownik, z którym ma zostać rozwiązana umowa o pracę, jest reprezentowany przez organizację związkową (Góral 2018, s. 334 i n.). Może to w rezultacie oznaczać pozyskanie przez pracodawcę informacji o pracowniku należącym do organizacji związkowej, a więc danych wrażliwych, albo danych o pracowniku niebędącym członkiem związku zawodowego, który złożył jedynie wniosek o obronę jego praw i interesów wobec pracodawcy, a zatem danych zwykłych. Jak słusznie zauważa Dominika Dörre-Kolasa, powyższa regulacja nie stanowi autonomicznej podstawy prawnej do uzyskania przez pracodawcę informacji o przynależności związkowej pracownika, a jedynie informacji dotyczących pracownika reprezentowanego przez organizację związkową (Dörre-Kolasa 2019, s. 378). Należy jednak wyrazić obawy, czy nie będzie to informacja, która może wskazywać na przynależność związkową pracownika.

Podstawą prawną przetwarzania informacji ujawniających przynależność związkową jest bez wątpienia przesłanka określona w art. 9 ust. 2 lit. d RODO. Odnosi się ona bezpośrednio do działalności związków zawodowych. Zgodnie z powyższą regulacją dopuszczalne jest przetwarzanie przedmiotowych danych w ramach uprawnionej działalności prowadzonej z zachowaniem odpowiednich zabezpieczeń przez niezarobkowy podmiot o celach związkowych, przy czym przetwarzanie to może dotyczyć wyłącznie

\footnotetext{
2 Odnotować warto, że w anglojęzycznym tekście RODO nie używa się sformułowania „prawo pracy”, a „dziedzina zatrudnienia” (the field of employment).

3 Zauważyć jednak trzeba, że jest to zgoda na dokonywanie potrąceń z wynagrodzenia za pracę w rozumieniu art. 91 k.p., nie zaś zgoda na przetwarzanie danych osobowych.
} 
członków takiego podmiotu, jego byłych członków lub osób utrzymujących z nim stałe kontakty w związku z jego celami. Zastrzega się ponadto, że dane nie mogą być ujawniane poza tym podmiotem bez zgody osób, których te dane dotyczą. O ile wskazana okoliczność nie budzi zastrzeżeń w ogólności, o tyle zakaz udostępniania informacji dotyczących członka organizacji związkowej pozostaje w pewnym stopniu w sprzeczności z istotą działalności związków zawodowych, gdyż w myśl art. 1 ust. 1 u.z.z. związek zawodowy to organizacja ludzi pracy powołana do reprezentowania i obrony ich praw, interesów zawodowych i socjalnych. Udostępnianie wskazanych danych wynika zatem ze specyfiki działalności związku zawodowego. Jak się wydaje, przystępując do organizacji związkowej, pracownik lub inna uprawniona do tego osoba powinny liczyć się z ewentualnością ujawnienia tych danych pracodawcy przez organizację związkową w zakresie niezbędnym do realizacji określonych prawem kompetencji związkowych. Dotyczy to zwłaszcza reprezentowania praw i interesów członków związku zawodowego w sprawach indywidualnych, co niejednokrotnie wymaga ujawnienia informacji o członkostwie danej osoby. Mając na względzie autonomiczny charakter przesłanek legalności przetwarzania danych osobowych, należałoby więc rozważyć powołanie się na wskazaną wcześniej podstawę prawną z art. 9 ust. 2 lit. b RODO w okolicznościach określonych przez ustawodawcę krajowego.

Zgoda na przetwarzanie danych szczególnie chronionych, w tym informacji o przynależności związkowej, może z kolei stanowić podstawę prawną przetwarzania tych danych, przy czym - zgodnie z art. 9 ust. 2 lit. a RODO - musi ona mieć charakter wyraźny (Litwiński, Barta, Kawecki 2018, s. 334-335). Dodatkowe obwarowania możliwości zastosowania tej przesłanki w sferze stosunków pracy wynikają $\mathrm{z}$ art. $22^{1 \mathrm{~b}} \S 1$ k.p. W świetle powyższej regulacji zgoda pracownika może być podstawą przetwarzania danych wrażliwych, których podania pracodawca nie jest uprawniony żądać, tylko wówczas gdy dane te zostaną udostępnione pracodawcy z inicjatywy pracownika, nie zaś na wniosek pracodawcy. Nie wydaje się, aby przesłanka ta znajdowała szerokie zastosowanie w procesach przetwarzania informacji ujawniających przynależność związkową, choć nie należy tego bezwzględnie wykluczać. Przetwarzanie tych danych jest bowiem związane z wykonywaniem praw lub obowiązków przez podmiot zatrudniający lub organizację związkową, jak również uprawnień członka związku zawodowego.

Wskazane powyżej podstawy prawne przetwarzania danych sensytywnych, w szczególności okoliczności wynikające z art. 9 ust. 2 lit. b i d RODO, mają - jak sądzę - podstawowe znaczenie w procesach przetwarzania informacji ujawniających przynależność związkową, choć katalog przesłanek legalności przetwarzania danych szczególnie chronionych jest znacznie bardziej obszerny.

\section{Uwagi końcowe}

Stosowanie określonych w art. 9 ust. 2 RODO podstaw prawnych przetwarzania informacji ujawniających przynależność związkową, przy uwzględnieniu polskich regulacji 
prawnych, budzi pewne wątpliwości. W szczególności nie jest jasne, czy organizacja związkowa, udostępniając pracodawcy informacje dotyczące członka tej organizacji, powinna powoływać się na okoliczność dedykowaną tego typu administratorom danych osobowych, to jest na art. 9 ust. 2 lit. d ROOD, i w związku z tym pozyskiwać zgodę podmiotu danych, czy też może - w pewnych okolicznościach - podstawę prawną udostępniania tych danych wywodzić z przepisów prawa krajowego w związku z art. 9 ust. 2 lit. b RODO. Pozytywnie należy natomiast ocenić przyjęcie przez prawodawcę unijnego szczególnego modelu ochrony w odniesieniu do informacji ujawniających przynależność związkową. Generalny zakaz ich przetwarzania bez wątpienia wzmacnia ich ochronę.

\section{Bibliografia}

Dörre-Kolasa D. (2019) Administrator danych osobowych w zbiorowym prawie zatrudnienia, „Studia z Zakresu Prawa Pracy i Polityki Społecznej”, nr 4.

Góral Z. (2018) [w:] K.W. Baran (red.), Kodeks pracy. Komentarz, Warszawa, komentarz do art. 38. Hajn Z. (2017) Inicjowanie i organizacja wyborów członków rady pracowników [w:] Tendencje rozwojowe indywidualnego i zbiorowego prawa pracy. Księga Jubileuszowa Profesora Grzegorza Goździewicza, Toruń.

Kulesza E. (2017) Prawo związków zawodowych do danych pracowników przetwarzanych przez pracodawce. Przetwarzanie danych osobowych $w$ procesie współdziałania pracodawcy ze związkami zawodowymi w sprawach indywidualnych [w:] D. Dörre-Kolasa (red.), Ochrona danych osobowych pracowników w świetle rozporządzenia Parlamentu Europejskiego i Rady (UE) 2016/679, Warszawa.

Litwiński P. (red.), Barta P., Kawecki M. (2018) Rozporządzenie UE w sprawie ochrony osób fizycznych w zwiazku z przetwarzaniem danych osobowych i swobodnym przepływem takich danych. Komentarz, Warszawa.

Wujczyk M. (2019) Nowe regulacje funkcjonowania związków zawodowych - wybrane zagadnienia, „Studia z Zakresu Prawa Pracy i Polityki Społecznej”, nr 3.

\section{Akty prawa międzynarodowego}

Dyrektywa 95/46/WE Parlamentu Europejskiego i Rady z dnia 24 października 1995 roku w sprawie ochrony osób fizycznych w zakresie przetwarzania danych osobowych i swobodnego przepływu tych danych, Dz.Urz. UE L 1995, nr 281.

Rozporządzenie Parlamentu Europejskiego i Rady (UE) nr 2016/679 z dnia 27 kwietnia 2016 roku w sprawie ochrony osób fizycznych w związku z przetwarzaniem danych osobowych i w sprawie swobodnego przepływu takich danych oraz uchylenia dyrektywy 95/46/WE (ogólne rozporządzenie o ochronie danych), Dz.Urz. UE L 2016, nr 119. 


\section{Akty prawa krajowego}

Ustawa z dnia 26 czerwca 1974 roku - Kodeks pracy, Dz.U. 2019, poz. 1040 tekst jedn. ze zm. Ustawa z dnia 23 maja 1991 roku o związkach zawodowych, Dz.U. 2019, poz. 263 tekst jedn. Ustawa z dnia 29 sierpnia 1997 roku o ochronie danych osobowych, Dz.U. 2016, poz. 922 tekst jedn. ze zm.

Ustawa z dnia 7 kwietnia 2006 roku o informowaniu pracowników i przeprowadzaniu z nimi konsultacji, Dz.U. 2006, nr 79, poz. 550 ze zm. 